\title{
Low avidity of human papillomavirus (HPV) type 16 antibodies is associated with increased risk of low-risk but not high-risk HPV type prevalence
}

Proscovia B Namujju ${ }^{1,2,3^{*}}$, Lea Hedman ${ }^{4}$, Klaus Hedman ${ }^{4}$, Cecily Banura ${ }^{5}$, Edward K Mbidde², Dennison Kizito², Romano N Byaruhanga ${ }^{6,7}$, Moses Muwanga ${ }^{8}$, Reinhard Kirnbauer ${ }^{9}$, Heljä-Marja Surcel ${ }^{1}$ and Matti Lehtinen ${ }^{3}$

\begin{abstract}
Background: Low avidity of antibodies against viral, bacterial and parasitic agents has been used for differential diagnosis of acute versus recent/past infections. The low-avidity antibodies may however, persist for a longer period in some individuals.

Findings: We studied the association of human papillomavirus (HPV) type 16 antibody avidity with seroprevalence to HPV types 6/11/18/31/33/45. Antibody avidity was analysed for 365 HPV16 seropositive pregnant Finnish and Ugandan women using a modified ELISA.

Low avidity of HPV16 antibodies was found in 15\% of Finnish and 26\% of Ugandan women. Ugandan women with low-avidity HPV16 antibodies had an increased risk estimate for HPV6/11 (odds ratio, OR 2.9; 95\%Cl 1.01-8.4) seropositivity but not to high-risk HPV types 18/31/33/45.
\end{abstract}

Conclusion: Association of the low avidity HPV16 antibody "phenotype" with possible susceptibility to infections with other HPV types warrants investigation.

Keywords: antibody avidity, genital infection, HPV, prevalence

\section{Background}

Persistent infections with high-risk human papillomavirus (hrHPV) type 16 cause half of cervical cancer (CxCa) morbidity/mortality $[1,2]$. Infections with multiple hrHPVs further increase the $\mathrm{CxCa}$ risk, and promote progression of cervical intraepithelial neoplasia (CIN) $[3,4]$. Vaccines against HPV16 and HPV18 (HPV16/18) have high protective efficacy against infections with the vaccine and some non-vaccine HPV types (31/45) and associated CIN [5-7]. Various other non-vaccine HPV types 33/35/52/58 are, also however, relatively prevalent in Finland and Uganda [8-11].

HPV16 causes genital infections. Following the infection, development of antibody response takes from 6 to 18 months [12,13]. During this time, HPV is resolved through $\mathrm{T}$ helper cell activation of cytotoxic $\mathrm{T}$ cells and $B$ cells to produce neutralizing IgG antibodies [12].

\footnotetext{
* Correspondence: Bazanya.Namujju@uta.fi

${ }^{1}$ National Institute for Health and Welfare, Oulu, Finland

Full list of author information is available at the end of the article
}

Immune response eliminates $\mathrm{HPV}$ in $90 \%$ of infected women [4].

Maturation of the IgG antibody avidity takes approximately 6 months [14-16]. This is used in the distinction of acute and recent/past infections with, e.g., toxoplasmosis, rubella, and parvovirus [17-20]. On the other hand, low-avidity antibodies have been found (outside the 6 months period) in chronic infections, e.g., cytomegalovirus (CMV) and HPV16 [21-23].

We evaluated whether presence of low-avidity of HPV16 antibodies is associated with an increased risk of prevalence for other HPV types.

\section{Material and methods}

Participants

A total of 4748 pregnant Finnish (2784) and Ugandan (1964) women participated in an epidemiological study [10]. In Finland, all pregnant women donate serum samples to Finnish Maternity Cohort (FMC) for the screening of congenital infections and consent to further

\section{() Biomed Central}


serological use of the samples for health-related research $[10,24]$. In Uganda all participating women consented for the use of the samples to serological HPV and other sexually transmitted infections research [10]. The study was approved by the institutional review boards at the National Institute for Health and Welfare (THL), Finland; Uganda Virus Research Institute; St Raphael of St Francis Hospital Nsambya, and Uganda National Council of Science and Technology.

\section{Laboratory analysis}

Chlamydia trachomatis and HIV antibodies, and serum cotinine (current smoking $>20 \mathrm{ng} / \mathrm{ml}$ ) were analysed by ELISA as described [10]. Standard ELISA for HPV6/11/ $16 / 18 / 31 / 33 / 45$ antibodies was used [10,24-27], with modifications [17-19] for HPV16 antibody avidity analysis. Briefly, Nunc ${ }^{\mathrm{TM}}$ micro plates were coated with HPV16 VLPs (kindly provided by Kathrin Jansen, Merck Research Labs, Philadelphia, PA) by overnight incubation at $4^{\circ} \mathrm{C}$. Samples were serially diluted: 1:1, 1:4, 1:16, 1:64, 1:256 in phosphate-buffered saline (PBS) with $10 \%$ fetal bovine serum (blocking buffer, BB). After blocking the plate, $50 \mathrm{ul}$ of diluted samples were added to wells A-D $(1: 4,1: 16,1: 64,1: 256)$ and wells E-H (1:1,1:4,1:16,1:64). To columns 1,2 and 3, blank, low and high avidity controls were added and incubated overnight at $4^{\circ} \mathrm{C}$ [28]. Wells A-D were washed 3 times with $200 \mathrm{ul}$ of PBS/0.05\% Tween $20(\mathrm{PBS}+\mathrm{T})$, and wells E-H were washed with $6 \mathrm{M}$ urea (Promega, Biofellows, Finland) in PBS. Each wash was for $5 \mathrm{~min}$. All wells were again washed two times with $\mathrm{PBS}+\mathrm{T}$, and wells $\mathrm{E}-\mathrm{H}$, treated with the $6 \mathrm{M}$ urea, were washed three extra times to remove excess urea. The primary and secondary antibodies were incubated for 90 and $60 \mathrm{~min}$. An ABTS-substrate was added and the reaction stopped after $40 \mathrm{~min}$. Optical densities (OD) of each control and individual samples were plotted: Curve 1: OD from urea wash and Curve 2: OD from PBS $+\mathrm{T}$ wash. Distance between the curves at OD 0.2 (IgG threshold) was measured and matched with corresponding avidity index [17-20]. Cut-off for low-avidity (30\%) was calculated from mean +3 SD of low-avidity controls added on each of the 40 plates, according to standard procedures [18-20]. The low avidity controls were identified by repeated measurements from sera obtained one month post third dose in conjunction of an HPV vaccination study.

\section{Statistical analysis}

Logistic regression was used to calculate the relative risk (odds ratio, OR, with 95\% confidence intervals, 95\% CI) of being HPV6/11/18/31/33/45 seropositive associated with low avidity HPV16 antibodies. Single HPV16 seropositives were the reference group. Adjustment was stepwise for age, Chlamydia trachomatis and HIV antibodies, and cotinine. Statistical analyses were done using Stata 8 (College Station, TX).

\section{Results and Discussion}

Overall, HPV16 seroprevelances were equal (21\%) in both countries [10]. Altogether 365 of the 994 originally HPV16 seropositive women [10] were randomly selected. Majority (248) were Finns (mean age of 22 years), 117 were Ugandans (mean age 23 years). Among the Finns 113 had HPV16 antibodies only, 36 had HPV16+ HPV6 or HPV11 antibodies, 59 had HPV16+ HPV31 or HPV33 antibodies, and 40 had HPV16+ HPV18 or HPV45 antibodies. Among the Ugandans 45 had HPV16 antibodies only, 32 had HPV16+ HPV6 or HPV11 antibodies, 24 had HPV16+ HPV31 or HPV33 antibodies, and 16 had HPV16+ HPV18 or HPV45 antibodies (Table 1).

Overall, the prevalence of low-avidity HPV16 antibodies was $15 \%$ (38/248) among the Finns and 26\% (30/ $117)$ among the Ugandans $(\mathrm{p}<0.0001)$. There was no statistically significant correlation (Pearson correlation co-efficient 0.07, p = 0.15) between HPV16 antibody avidity and age (Figure 1). The seroprevalences of HIV, C. trachomatis, and smoking were $0 \%, 25 \%$ and $23 \%$ $(16 / 69$, cotinine data available) among the Finns and $9 \%$, $27 \%$ and $2 \%(2 / 111$, questionnaire data available) among the Ugandans.

HPV6/11 seropositivity was increased in women who had low-avidity HPV16 antibodies (crude OR 2.4, 95\%CI 1.3-4.6). After stratification by country and adjustment, increased risk for being HPV6/11 seropositive was found only among the Ugandans (adjusted OR 2.9, 95\% CI 1.01-8.4). Estimates on the association of low-avidity with seropositivity for other hrHPVs were not different from unity (Table 2).

HPV16 seropositivity is associated with increased risk of acquiring other HPVs $[10,26,29]$. The prevalence of low-avidity of HPV16 antibodies was $15 \%$ and $26 \%$ among pregnant Finnish and Ugandan women, respectively. Sexual risk-taking behavior also predisposes women to various HPV types earlier in Uganda than in Finland [10]. Thus, the Ugandans had more time to get infected with both HPV16 and other HPV infections than the Finns. There were, however, higher proportions of HPV16 seropositive Ugandans with low-avidity HPV16 antibodies and increased risk of HPV6 or 11 prevalence.

Low-avidity antibodies induced by microbial antigens alone are less variable and less functionally versatile than those induced with T-cell help $[14,30]$. In immuno-compromized patients low-avidity cytomegalovirus antibodies can persist for several months [21,22]. Comparable delayed maturation of HPV16 antibody avidity, probably 
Table 1 Association (odds ratio, OR, with 95\% confidence interval, Cl) of low avidity HPV16 antibodies (ab) with increased risk of being seropositive for other HPV types among Finnish and Ugandan women

\begin{tabular}{|c|c|c|c|c|}
\hline Population & Seropositivity & Total & Prevalence of low ab-avidity (\%) & Crude OR $(95 \% \mathrm{Cl})$ \\
\hline \multirow[t]{4}{*}{ Finland $(n=248)$} & HPV16 only & 113 & $19(7.7 \%)$ & 1 \\
\hline & HPV $16+6$ or 11 & 36 & $8(6.3 \%)$ & $1.4(0.6-3.6)$ \\
\hline & HPV16 + 31 or 33 & 59 & $5(2.5 \%)$ & $0.5(0.2-1.3)$ \\
\hline & HPV16 + 18 or 45 & 40 & $6(2.2 \%)$ & $0.9(0.3-2.4)$ \\
\hline \multirow[t]{4}{*}{ Uganda $(n=117)$} & HPV16 only & 45 & $9(7.7 \%)$ & 1 \\
\hline & HPV $16+6$ or 11 & 32 & $15(12.8 \%)$ & $3.5(1.3-9.7)$ \\
\hline & HPV16 + 31 or 33 & 24 & $4(3.4 \%)$ & $0.8(0.2-2.9)$ \\
\hline & HPV16 + 18 or 45 & 16 & $2(1.7 \%)$ & $0.6(0.1-4.0)$ \\
\hline \multirow[t]{4}{*}{ All $(n=365)$} & HPV16 only & 158 & $28(7.7 \%)$ & 1 \\
\hline & HPV $16+6$ or 11 & 68 & $23(6.3 \%)$ & $2.4(1.3-4.6)$ \\
\hline & HPV16 + 31 or 33 & 83 & $9(2.5 \%)$ & $0.6(0.3-1.3)$ \\
\hline & HPV16 + 18 or 45 & 56 & $8(2.2 \%)$ & $0.8(0.3-1.8)$ \\
\hline
\end{tabular}

All = combined data of Finnish and Ugandan women

Cutoff_30\% = using low avidity controls mean plus 3 standard deviations

associated with impaired ability to produce high quality neutralizing antibodies, identified women with increased risk for HPV6 or HPV11 seropositivity, possibly due to increased susceptibility. On the other hand, the first evidence from the HPV vaccination studies showed that following HPV vaccination, there was no correlation between avidity and neutralization capacity of the vaccine induced antibodies [31]. Why only the lrHPV occurrence was increased in our study remained unclear.

HPV16 seropositives only were eligible for the study. Thus, due to moderate sensitivity (75\%) of HPV16 serology [28] some HPV16 infected women could have been excluded. Moreover, even if HPV seropositivity is an indicator of cumulative incidence of HPV infections

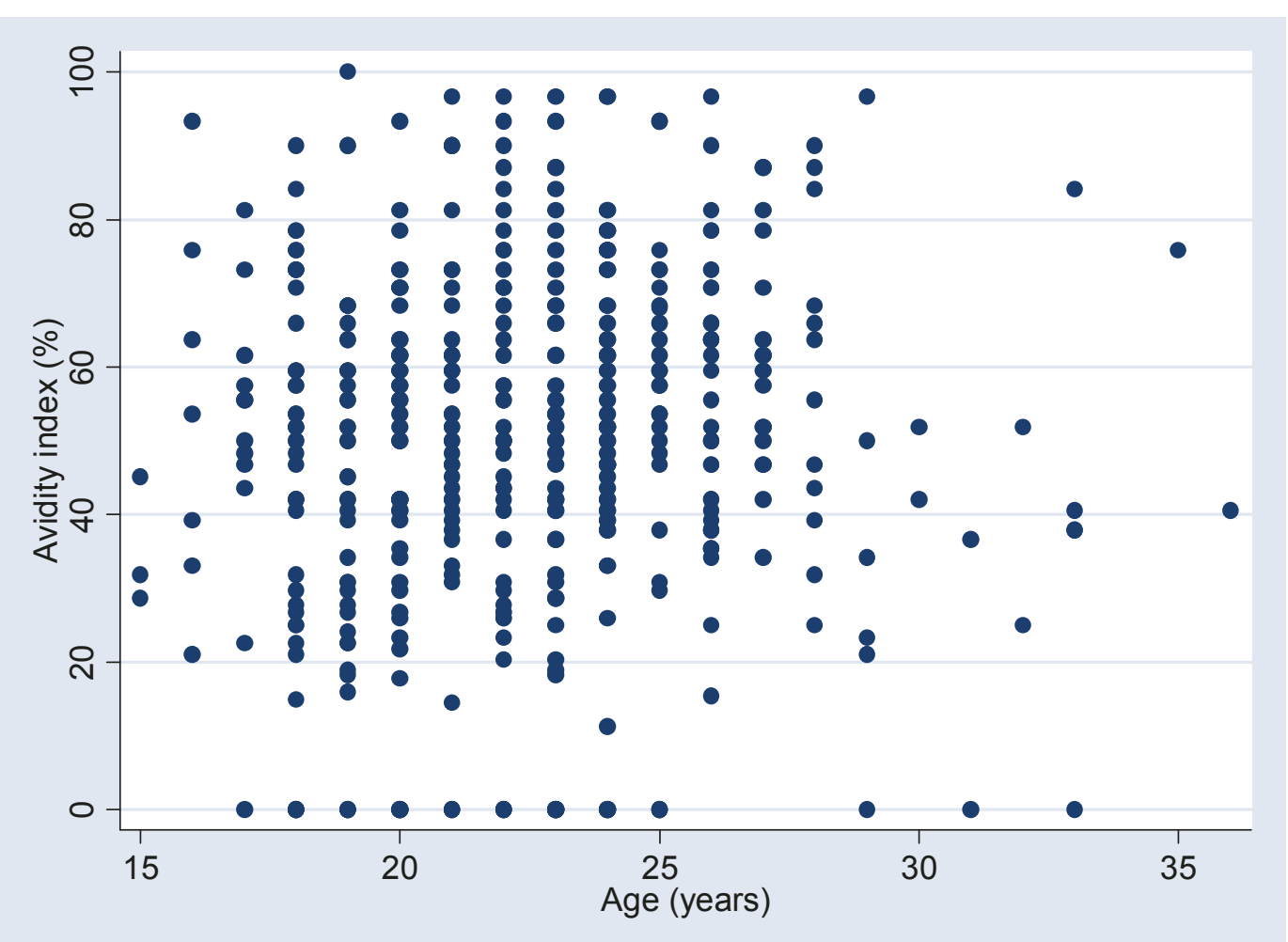

Figure 1 Correlation between antibody avidity and age (Pearson correlation co-efficient $0.07, p=0.15$ ) 
Table 2 Association (adjusted odds ratio, OR, with 95\% confidence interval, $\mathrm{CI}$ ) of low avidity HPV16 antibodies with increased risk of being seropositive for other HPV types among Finnish and Ugandan women

\begin{tabular}{|c|c|c|c|c|}
\hline Population & Seropositivity & $\begin{array}{l}\mathrm{OR}^{1}(95 \% \\
\mathrm{CI})\end{array}$ & $\begin{array}{l}\mathrm{OR}^{2}(95 \% \\
\mathrm{Cl})\end{array}$ & $\begin{array}{l}\mathrm{OR}^{3}(95 \% \\
\mathrm{Cl})\end{array}$ \\
\hline \multirow{4}{*}{$\begin{array}{l}\text { Finland }(\mathrm{n}= \\
248)\end{array}$} & HPV16 only & 1 & 1 & 1 \\
\hline & $\begin{array}{l}\text { HPV16 + } 6 \text { or } \\
11\end{array}$ & $1.1(0.4-2.8)$ & $1.9(0.6-6.1)$ & $0.8(0.1-6.8)$ \\
\hline & $\begin{array}{l}\text { HPV + } 31 \text { or } \\
33\end{array}$ & $0.3(0.1-1.0)$ & $0.3(0.1-1.3)$ & $0.8(0.0-1.0)$ \\
\hline & $\begin{array}{l}\text { HPV + } 18 \text { or } \\
45\end{array}$ & $0.7(0.2-1.8)$ & $0.5(0.1-2.0)$ & $0.3(0.2-3.8)$ \\
\hline \multirow{4}{*}{$\begin{array}{l}\text { Uganda }(n= \\
117)\end{array}$} & HPV16 only & 1 & 1 & 1 \\
\hline & $\begin{array}{l}\text { HPV } 16+6 \text { or } \\
11\end{array}$ & $3.5(1.3-9.7)$ & $3.0(1.1-8.5)$ & $\begin{array}{l}2.9\left(1.0^{*}-\right. \\
8.4)\end{array}$ \\
\hline & $\begin{array}{l}\text { HPV + } 31 \text { or } \\
33\end{array}$ & $0.8(0.2-2.9)$ & $0.7(0.2-2.5)$ & $0.6(0.2-2.3)$ \\
\hline & $\begin{array}{l}\text { HPV + } 18 \text { or } \\
45\end{array}$ & $0.6(0.1-3.0)$ & $0.5(0.1-2.9)$ & $0.5(1.0-2.8)$ \\
\hline
\end{tabular}

Cutoff_30\% = using low avidity controls mean plus 3 standard deviations $\mathrm{OR}^{1}=$ adjusted for age

$\mathrm{OR}^{2}=$ adjusted for age, Chlamydia trachomatis, HIV

$\mathrm{OR}^{3}=$ adjusted for age, C. trachomatis, HIV and smoking

*1.0 = lower $95 \%$ confidence limit 1.01

$[12,25,28]$ our cross-sectional approach did not reveal the order of acquiring the various HPV infections.

The association was seen only in the Ugandans, whose HIV seroprevalence was 9\%. Adjusting for HIV, however, had no effect on the low-avidity associated risk, antibody avidity is not affected by HIV infection $[21,22]$. Smoking, which impairs HPV antibody response [27], might, however, intervene with the development (maturation) of antibody avidity as the observed association almost lost statistical significance after adjusting for smoking. In conclusion, association of the low avidity HPV16 antibody "phenotype" with possible susceptibility to other HPV infections warrants investigation.

\section{Conflict of interests}

PBN, CB, LH, KH, EKM, RB, MM, RK, HMS declare no conflicts of interest. ML has obtained grants from Merck\&Co. Inc. and GSK-Biologicals for HPV vaccination studies through his employers.

\section{Acknowledgements}

We thank the National Institute for Health and Welfare laboratory staff, Oulu, Finland, and the Entebbe Hospital, Nsambya Hospital and Naguru Health Centre Antenatal Clinics staff, Uganda.

The EU-FP6 Network: Cancer Control using Population Registries and Biobanks (CCPRB) and Finnish Cancer Society funded this study.

\section{Author details}

${ }^{1}$ National Institute for Health and Welfare, Oulu, Finland. ${ }^{2}$ Uganda Virus Research Institute, Entebbe, Uganda. ${ }^{3}$ School of Public Health, University of
Tampere, Finland. ${ }^{4}$ Department of Virology, University of Helsinki and Huslab, Helsinki, Finland. ${ }^{5}$ College of Health Sciences, Makerere University, Kampala, Uganda. ${ }^{6}$ Department of Obstetrics and Gynecology, San Raphael of St. Francis Hospital, Nsambya, Uganda. ${ }^{7}$ Department of Public Health Sciences, Karolinska Institute, Stockholm, Sweden. ${ }^{8}$ Entebbe Hospital, Entebbe, Uganda. ${ }^{9}$ Department of Dermatology, Medical University Vienna, Austria.

\section{Authors' contributions}

PBN, designed, ran the study, conducted data collection and analysis and wrote the report.

$M L$ designed the study, supervised PBN in data analysis, data interpretation and report writing. $\mathrm{KH}$, developed the modified ELISA. KH, LH, HMS supervised PBN in laboratory analysis and contributed to data interpretation and report writing. KD processed the samples. EKM, CB, RB, MM, RK, contributed to study design. All authors read and approved the final manuscript.

Received: 28 September 2010 Accepted: 6 June 2011 Published: 6 June 2011

\section{References}

1. Ferlay J, Bray F, Pisani P, Parkin MD: GLOBOCAN 2002: Cancer incidence, mortality and prevalence worldwide. IARC Cancer Base. 2.0 edition. IARC, Lyon; 2004.

2. Walboomers JM, Jacobs MV, Manos MM, Bosch FX, Kummer JA, Shah KV, Snijders PJ, Peto J, Meijer CJ, Muñoz N: Human papillomavirus is a necessary cause of invasive cervical cancer worldwide. J Pathol 1999, 189:12-9.

3. Ho GY, Studentsov Y, Bierman R, Beardsley L, Lempa M, Burk RD: Risk factors subsequent cervicovaginal human papillomavirus (HPV) infection and the protective role of antibodies to HPV-16 virus like particles. $J$ Infect Dis 2002, 186:737-42

4. Trottier H, Mahmud S, Costa MC, Sobrinho JP, Duarte-Franco E, Rohan ET, Ferenczy A, Villa LL, Franco EL: Human papillomavirus infections with multiple types and risk of cervical neoplasia. Cancer Epidemiol Biomarkers Prev 2006, 15:1274-80.

5. Brown DR, Kjaer SK, Sigurdsson K, Iversen OE, Hernandez-Avila M, Wheeler CM, Perez G, Koutsky LA, Tay EH, Garcia P, et al: The impact of quadrivalent human papillomavirus (HPV; types $6,11,16$, and 18) L1 virus-like particle vaccine on infection and disease due to oncogenic nonvaccine HPV types in generally HPV-naive women aged 16-26 years. J Infect Dis 2009, 199:926-35.

6. Paavonen J, Naud P, Salmerón J, Wheeler CM, Chow SN, Apter D, Kitchener H, Castellsague X, Teixeira JC, Skinner SR, et al: Efficacy of human papillomavirus (HPV)-16/18AS04-adjuvanted vaccine against cervical infection andprecancer caused by oncogenic HPV types (PATRICIA):final analysis of a double-blind, randomised study inyoung. Lancet 2009, 374:301-14.

7. Villa L, Perez G, Kjaer S, Lehtinen M, Paavonen J, Munoz N, Sigurdsson K, Hernandez-Avila M, Iversen OE, Thoresen S, et al: Prophylactic use of human papillomavirus (HPV) L1 virus-like particle vaccine significantly reduces intraepithelial neoplasia grade 2 , grade 3 and adenocarcinoma in situ risk. Lancet 2007, 369:1861-8.

8. Auvinen E, Niemi M, Malm C, Zilliacus R, Trontti A, Fingerroos R, Lehtinen $M$, Paavonen J: High prevalence of HPV among female students in Finland. Scand J Infect Dis 2005, 37:873-6.

9. Banura C, Franceschi S, van Doorn LJ, Arslan A, Kleter B, WabwireMangen F, Mbidde EK, Quint W, Weiderpass E: Prevalence, incidence and clearance of human papillomavirus infection among young primiparous pregnant women in Kampala, Uganda. Int J Cancer 2008, 123:2180-7.

10. Namujju PB, Surcel HM, Kirnbauer R, Kaasila M, Banura C, Byaruhanga R, Muwanga M, Mbidde EK, Koskela P, Lehtinen M: Risk of being seropositive for multiple human papillomavirus types among Finnish and Ugandan women. Scand J Infect Dis 2010, 42:522-6.

11. Paavonen J, Halttunen M, Hansson BG, Nieminen P, Rostila R, Lehtinen M: Prerequisites for human papillomavirus vaccine trial: results of feasibility studies. J Clin Virol 2000, 19:25-30.

12. Dillner J: The serological response to papillomaviruses. Sem Cancer Biol 1999, 9:423-30.

13. Wikstrom A, Van Doornum GJJ, Quint WGV, Schiller JT, Dillner J: Identification of human papillomavirus seroconversions. J Gen Virol 1995, 76:529-39. 
14. Bachmann MF, Kalinke U, Althage A, Freer G, Burkhart C, Roost H, Aguet M, Hengartner $\mathrm{H}$, Zinkernagel RM: The role of antibody concentration and avidity in antiviral protection. Science 1997, 276:2024-7.

15. Nakanishi Y, Bao Lu, Gerard C, Lwasaki A: CD8 ${ }^{+}$T lymphocyte mobilization to virus-infected tissue requires $\mathrm{CD}^{+}{ }^{+}$T-cell help. Nature 2009, 462:510-3.

16. O'Rourke L, Tooze R, Fearon DT: Co-receptors of B lymphocytes. Curr Opin Immunol 1997, 9:324-9.

17. Hedman K, Lappalainen M, Seppala I, Makela O: Recent primary toxoplasma infection indicated by a low avidity of specific lgG. J Infect Dis 1989, 159:736-40.

18. Hedman K, Rousseau SA: Measurement of avidity of specific lgG for verification of recent primary rubella. J Med Virol 1989, 27:288-92.

19. Herne V, Hedman K, Reedik P: Immunoglobulin $G$ avidity in the serodiagnosis of congenital rubella syndrome. Eur J Clin Microbiol Infect Dis 1997, 16:763-6.

20. Soderlund M, Brown CS, Cohen BJ, Hedman K: Accurate serodiagnosis of B19 Parvovirus by measurement of IgG avidity. J Infect Dis 1995, 14:354-61.

21. Bodeus M, Feyder S, Goubau P: Avidity of IgG antibodies distinguishes primary from non-primary cytomegalovirus infections in pregnant women. Clin Diag Virol 1998, 9:9-16.

22. Lazzarotto T, Varani S, Spezzacatens P, Praadelli P, Poteni L, Lombardi A, Ghasetti V, Gabrielli L, Abate AD, Magelli C, Landini PM: Delayed acquisition of high avidity anti-cytomegalovirus antibody is correlated with prolonged antigenemia in solid organ transplant receipts. J Infect Dis 1998, 178:1145-9.

23. Lehtinen M, Parkkonen P, Luoto H, Ylä-Outinen A, Romppanen U, Rantala I, Paavonen J: Antipeptide IgA antibodies to a human papillomavirus type 16 E2 derived synthetic peptide predict the natural history of cervical HPV infection. Serono Symposia Pub 1990, 78:509-19.

24. Lehtinen $M$, Kaasila M, Pasanen $K$, Patama T, Palmroth J, Laukkanen $P$, Pukkala E, Koskela P: Seroprevalence atlas of infections with oncogenic and non-oncogenic human papillomaviruses in Finland in the 1980s and 1990s. Int J Cancer 2006, 119(11):2612-9.

25. Dillner J, Kallings I, Brihmer C, Sikström B, Koskela P, Lehtinen M, Schiller JT, Sapp M, Mardh PA: Seropositivities to human papillomavirus types 16,18 or 33 capsids and to Chlamydia trachomatis are markers of sexual behavior. J Infect Dis 1996, 173:1394-8.

26. Palmroth J, Namujju P, Simen-Kapeu A, Kataja V, Surcel HM, Tuppurainen M, Yliskoski M, Syrjänen $K$, Lehtinen M: Natural seroconversion to high risk human papillomaviruses (hrHPVs) is not protective against related HPV genotypes. Scand J Inf Dis 2010, 42:379-84.

27. Simen-Kapeu A, Kataja V, Yliskoski M, Syrjänen K, Dillner J, Koskela P, Paavonen J, Lehtinen M: Smoking impairs human papillomavirus (HPV) type 16 and 18 capsids antibody response following natural HPV infection. Scand J Infect Dis 2008, 40:745-51.

28. Kjellberg L, Wang Z, Wiklund F, Edlund K, Angstrom T, Lenner P, Sjoberg L, Hallmans G, Wallin KL, Sapp M, Schiller J, Wadell G, Mahlck CG, Dillner J: Sexual behaviour and papillomavirus exposure in cervical intraepithelial neoplasia: a population based case-control study. J Gen Virol 1999, 80:391-8.

29. Kaasila M, Koskela P, Kirnbauer R, Pukkala E, Surcel H-M, Lehtinen M: Population dynamics of serologically defined infections with HPV11/16/ 18/31 in fertile-aged women. Int I Cancer 2009, 25:2166-77.

30. Stavnezer J: Immunoglobulin class switching. Curr Opin Immunol 1996, 8:199-205

31. Dauner JG, Pan Y, Hildesheim A, Harro C, Pinto LA: Characterization of the HPV-specific memory B cell and systemic antibody responses in women receiving an unadjuvanted HPV16 L1 VLP vaccine. Vaccine 2010, 28:5407-13.

doi:10.1186/1756-0500-4-170

Cite this article as: Namujju et al.: Low avidity of human papillomavirus (HPV) type 16 antibodies is associated with increased risk of low-risk but not high-risk HPV type prevalence. BMC Research Notes 2011 4:170.

\section{Submit your next manuscript to BioMed Central and take full advantage of:}

- Convenient online submission

- Thorough peer review

- No space constraints or color figure charges

- Immediate publication on acceptance

- Inclusion in PubMed, CAS, Scopus and Google Scholar

- Research which is freely available for redistribution

Submit your manuscript at www.biomedcentral.com/submit
Biomed Central 